Received: November 30, 2017

Revision received: January 24, 2018

\title{
Empirical Study on the Effectiveness of Teaching Model of College English Writing within Blended Learning Mode
}

\author{
Chunyi Zhou \\ Ankang University
}

\begin{abstract}
Based on connectivism and writing as process approach, this paper aims to construct a teaching model within the blended learning mode. Then, this teaching model will be practiced in English writing class for 16 weeks. According to writing exam, 64 students are selected to be our participants in the research. 32 students are classified in the control group in which traditional teaching mode is employed in writing class. Other 32 students are defined as experiment group in which students are taught in the teaching model within the blended learning mode. The data from pre-test and post-test have been made in paired sample $\mathrm{T}$ tests. The results from online course platform and pre-test and post-test suggest that the teaching model within blended learning mode can significantly improve students' English writing ability in terms of four aspects: content relevance, content sufficiency, organization structure and language expression.
\end{abstract}

\section{Keywords}

Blended Learning Mode $•$ Teaching Model $•$ English Writing Ability $\bullet$ Effectiveness

Ankang University, Ankang 725000, China. Email: 908930506@qq.com

Citation: Zhou, C. Y. (2018). Empirical Study on the Effectiveness of Teaching Model of College English Writing within Blended Learning Mode. Educational Sciences: Theory \& Practice, 18(5), 1060-1076.

http://dx.doi.org/10.12738/estp.2018.5.009 
ESL/EFL has been studied since 1980s. The way to teach English went through several stages. In the early stage, translation method was dominant in classroom English teaching in which mother tongue was used to explain English knowledge and grammar training was focused. The structure and grammar models were imitated by students. As the structuralism was influential in linguistic theory, language was understood as different layers such as phoneme, morpheme, phrase and sentence etc. Then, teaching methodology was transformed into audio-lingual approach. The teaching materials were arranged into dialogue, and emphasized the accurate pronunciation; made full use of language labs, accessible listening equipment. In other words, listening and speaking were stressed in English teaching; teacher was a controller in the whole class. Later, as cognitive method was brought into linguistics, language learning was expounded that students were encouraged to take active participation in classroom teaching because they have the cognitive competence to identify the potential rules in all types of language materials. Since then, ESL/EFL was in a new era. Subsequent communicative teaching method and task-based teaching method started to shift from language form to meaning expression; from teacher-centered teaching to student-centered teaching in English classroom. Moreover, English ability training was converted from grammar-patterned, speaking-listening ability to comprehensive ability---speaking, listening, reading and writing etc.

Based on the review of language teaching methodology above, it can be found that traditional teaching is restricted in the classroom; the relation between teacher and student seems to be authority--receiver. The technological tools are ignorant in teaching. ESL/EFL has been complained a lot in recent years. But it is a fact that digital era has brought new environment to education. Many IT companies created new functions and developed new platforms for learning in computer and related mobile online learning equipment. In college, MOOCs, flipped classroom have emerged as IT continues to be applied in education. In the USA, "bring your own device" (BYOD) has been the norm in K-12 education, and the MOOCs provided by Khan Academy, Coursera, Edix and Udesity have offered millions of people throughout the world free online courses. Therefore, it is a tendency that traditional classroom learning and online learning are being combined in ESL/EFL, which is also defined as blended learning. Varieties of scholars started to research the blended learning in education. English writing is an important part in ESL/EFL. Conventional English writing activity is enclosed in physical classroom. Time and space are quite restricted. Many scholars studied Chinese English writing in every possible aspect of writing. Li \& Li (2003) made a general search on English writing papers which are published in 8 Chinese major core journals about foreign language. Their research results suggest that from 1993 to 2002 , those English writing essays tended to cover every central part such as teaching methodology, test and evaluation, textual structure, relevant factors related with writing such as anxiety, and types of students' writing errors. But the current studies ignore the experimental method and similar contents are repeated. Hence, their research predicts that English writing is going to be studied with more comprehensive methods and computerrelated technology will be widely employed in writing.

As computer and mobile equipment are widely employed, English writing classes have been necessarily affected. Some scholars have made relevant studies on English writing with the computer-assisted technology. But most studies focused on the general and rough analysis of the teaching mode or learning mode, for example, Han \& Hu (2011) studied the teaching mode of English writing center with the assistance of internet-based platform. Their research result indicates that internet-based English teaching center can stimulate students' 
individualized learning mode, and give immediate feedback to students' writing task. Therefore, this paper attempts to employ an experimental method to testify how the blended learning improves English writing ability of English major students in terms of content, logical structure and language expression. The teaching model within blended learning mode focuses on the combination of online course platform learning mode and faceto-face learning mode, which stresses the writing process instead of writing product. The online course platform will record the interaction between students and prewriting activities, between students and their peers, between students and teacher's feedback. According to the previous studies and connectivism, this paper aims to propose one hypothesis: the teaching model within the blended learning mode can significantly improve college students' English writing ability.

\section{Literature Review}

\section{Theoretical Basis}

Connectivism. With the rapid development of hi-technology, the way to teach and learn has also been affected. The traditional learning theories, such as behaviorism, cognitivism and constructivism, have focused on explaining how the learners are processing information in their internal mind, either passive training or active constructing knowledge through experience. All of them occurred when IT did not play an important role in learning. However, nowadays knowledge is growing dramatically and we must adjust ourselves to the new information explosion age. Computer and mobile electronic equipment have become an indispensable part in learning and teaching. The old classroom plus textbook learning style must be changed. Thus, it is crucial to integrate high technology into learning and teaching. Correspondingly, learning theory need to include the impact of IT to explain how humans learn in an information age. George (2008) proposes a new learning theory--Connectivism: an integration of chaos, network, complexity and self-organization. The main contents of Connectivism are as follows: learning and knowledge are built upon all kinds of nodes; learning is a process to connect various professional nodes or information resources; learning may reside in nonhuman appliance; the capacity to keep continual learning is more important than what is possessed in mind; sharing and connection are the final target of learning activities in view of connectivism. In a word, connectivism defines learning not as an individual activity but as an activity to refine learners' internal and external learning network, which takes the individual learner as basic unit and constructs a complicated learning network with other individual members in the social network. This network will be integrated into all types of organizations and institutions, which interact with individual learner's knowledge and stimulate the networked learners to achieve incessant improvement.

Connectivism pays much importance to the innovation in learning, which will accelerate the growth of knowledge, the formation of network (Wang Zhijun \& Chen Li, 2014). The innovation is achieved upon the learners' consistent understanding of the relevance among fragmented information. Therefore, in such kind of learning environment, one must have two fundamental abilities---the wayfinding ability and sensemaking ability. (George, 2011) The following Figure1 explains the different levels of interaction and their logical connections in terms of connectivism. It clearly suggests that media is a basic element to construct different 
levels of interaction. The highest level of interaction lies in the innovation to achieve the integration of old and new concept and form a connected network for knowledge growth.

Table1

The Process of Teaching Interaction Level

\begin{tabular}{|c|c|c|c|}
\hline Category & $\begin{array}{c}\text { Three Levels of } \\
\text { interaction }\end{array}$ & Content for each level & feature \\
\hline $\begin{array}{l}\text { Operation } \\
\text { interaction }\end{array}$ & Level1 & Student-social media interaction & Operation interaction \\
\hline $\begin{array}{l}\text { Information } \\
\text { interaction }\end{array}$ & Level2 & $\begin{array}{l}\text { Student-teacher interaction; } \\
\text { Student-student interaction; } \\
\text { Student-learning resources } \\
\text { interaction }\end{array}$ & $\begin{array}{l}\text { wayfinding } \\
\text { interaction; } \\
\text { sensemaking } \\
\text { interaction }\end{array}$ \\
\hline $\begin{array}{l}\text { Concept } \\
\text { interaction }\end{array}$ & Level3 & $\begin{array}{l}\text { Old and New Concept } \\
\text { interaction }\end{array}$ & $\begin{array}{l}\text { innovation } \\
\text { interaction }\end{array}$ \\
\hline
\end{tabular}

Wang Zhijun \& Chen Li (2015) insert a further parameter into table 1. They borrow cognitive participation level to explain the four levels of interaction. Cognitive participation level is based on the revised classification from Anderson, including recitation, comprehension, application, analysis, comment and innovation. (Anderson et al., 2000) Then, table 2 was modified into table 2.

Table 2

Cognitive Participation Level in Each Level of Interaction

\begin{tabular}{|c|c|c|}
\hline Category & $\begin{array}{c}\text { Three Levels of } \\
\text { interaction }\end{array}$ & Cognitive participation \\
\hline Operation interaction & Level1 & recitation \\
\hline $\begin{array}{l}\text { Wayfinding } \\
\text { interaction }\end{array}$ & Level2 & $\begin{array}{l}\text { Recitation; Comprehension; application; } \\
\text { analysis; comment }\end{array}$ \\
\hline $\begin{array}{l}\text { Sensemaking } \\
\text { interaction }\end{array}$ & Level3 & $\begin{array}{l}\text { Comprehension; application; analysis; } \\
\text { comment; }\end{array}$ \\
\hline Innovation interaction & Level4 & innovation \\
\hline
\end{tabular}

Table 2 states the connection between each level of interaction and cognitive participation level. In the operation interaction, learners are only necessary to construct learning environment with the aid of social media. In this process, recitation is involved. In the wayfinding interaction, learners are required to search and locate the needed information from complicated information resources. Therefore, learners not only recite the location to filter out necessary information but also have to comprehend the information and further make comments. in sensemaking interaction, learners are urged to identify the pattern, which includes comprehension, application, analysis and comment in terms of cognitive participation level. It is quite clear that innovation interaction is the most demanding part for learners because it stresses the creation of new content or generation of new plan to keep constant connection in network. As the cognitive participation level increases, the challenge to the learners is becoming stronger.

In the digital age, the ability to employ the social media has become an indispensable part in learning process. English writing is a process to train learners' skill and cultivate their cognitive ability to express their view of point. In this aspect, the close connection between cognitive participation level and interaction level is reasonable to explain the writing process. Therefore, this paper tries to use this teaching interaction model to explain the effectiveness of blended learning on the English writing ability of college students.

Writing as a Process Approach. writing is considered as a product in early language teaching, which is 
influenced by structural linguistics. This orientation basically views ESL/EFL writing as filling words, sentences into prescribed patterns. In the classroom, there are three fixed steps: first, the teacher introduces classical samples and models. Second, the students are guided to appreciate the structure of the sample. At last, the students are required to develop an essay within the pattern of sample. This rigid style has restricted students' cognitive ability and critical thinking. It puts too much emphasis on the formal accuracy and grammar instead of meaningful communication. Frustrated with results of product approach, researchers of ESL/EFL writing started to reflect on this problem and resort to process approach to explain the nature of English writing. They came to view that writing is a complex, nonlinear, creative process.

Contrasted with product approach, ESL/EFL writing mode has converted into following 4 steps: prewriting, drafting, revising and editing. In this light of this understanding, ESL/EFL writing is a process to train learners' ability to express themselves and find their own voice on the given topic. The focus shifts to the content, idea instead of form accuracy. The classroom teaching is changed from teacher-centered mode to student-centered mode. English writing is not taught by teacher, on the contrary, learners learn by themselves. Therefore, in the view of process approach, learners are given much freedom to create different learning environment and express their own idea. The teacher functions as a guide to direct students searching writing materials and check their preparation for writing. What's more, the teacher needs to give immediate feedback to students' performance. In turn, students are to revise their drafts with the help of peer's feedback and teacher's feedback. Thus, blended learning provides students with a flexible and mobile platform to process-based writing mode.

Previous Studies. Based on Vygotsky's Sociocultural Theory of Mind and the latest development of assessment theories, Zhang Yanhong (2008) discusses the dynamic assessment (DA) mode for online EFL writing classes. She applies DA into every stage of students' English writing such as prewriting, drafting, peercorrection, revising, teacher-correction and final draft. For each stage, teachers are supposed to design different activities and strategies to help students to finish corresponding tasks. Her research results show that resource intervention, strategy intervention and incentive intervention from teachers are the significant factors to stimulate students' interests in English writing. Her experiment further consolidates the point that DA can effectively improve students' English writing qualities.

Li Hang \& Liu Rude (2011) make a research on the collaborative English writing style. Based on the questionnaire, interview and network course platform, it is found that network course platform can significantly improve Non-English major students' writing ability. In their paper, they quantify English ability as English writing interest, self-efficacy in English writing, and collaborative ability in group. Their research result also suggests that this newly web-based writing platform is helpful to construct students' self-controlling in writing and improve their ability to comment their peers' works. Furthermore, the communication and interaction between teachers and students or between students has been greatly strengthened. During this process, students improve their language-monitoring ability and cultivate their awareness of self-study. They propose that their research reverifies the optimization of teaching efficiency with the aid of network platform.

Liu Bing, Ge Lingling \& Li Guangwei (2012) employ an experimental method to investigate the teaching mode of college English writing based on the network corpus linguistics. They contrast two different teaching methods in English writing: traditional classroom teaching and corpus linguistic-based network teaching. Their 
research reveals that corpus-based network teaching can significantly improve their writing quality. The questionnaire result shows that corpus-based network can give students opportunity to learn self-analysis and deduce the rules from varieties of language materials on the platform. Majority of students reflect that the platform attaches much importance to the individual demand for English writing; their individualized learning method and learning environment can be generated. The experiment also concludes that with the improvement of English writing ability, the students' comprehensive language application abilities have been strengthened, including listening comprehension, reading comprehension and translation.

Yang Xiaoqiong \& Dai Yuncai (2015) studies the application of online Automated Essay Scoring system in college English writing. Specifically, they discuss the online scoring website www.pigai.org and suggest that www.pigai.org can give an immediate feedback and systematic evaluation to students' writing assignments in terms of syntactic features, semantic features, collocations, spellings etc. Their experiment results testify that www.pigai.org can effectively improve students' writing ability in the following aspects: coherence, grammar, structure, vocabulary, sentence type. The questionnaire and interview claim that their writing experiences in www.pigai.org develop their ability to search information, filter out the necessary information and revise their drafts, reducing their anxiety in writing and enhancing their motivation, self-efficacy.

All these reaches above indicate a tendency that in recent decades internet-based technology has swept into ESL/EFL writing class. Their researches mainly focus on the teaching mode within the network-based learning platform and learning environment. The subjects in their experiments are mostly chosen from Non-English majors. But as English major students, they have English writing classes and get more chances to finish writing tasks with online technical course platform. They have more channels to interact with their peers and teachers in English writing. Therefore, this paper attempts to quantify how the blended learning mode (online+face-toface) affects the writing ability of college English major students.

\section{Experiment Design}

Research Question. In view of connectivism and relevant studies, the author put forward one research question: Can the teaching model within the blended learning mode effectively improve English writing ability of English major students?

Participants. Based on the average score of pre-test writing, two classes from English major in Ankang College are chosen to be participants in our experiment. There are 32 students in each class. It is also investigated that English writing course for these two classes have been taught in the traditional mode. It means that teacher provides the classical writing samples to students in the physical classroom and guide the students to appreciate the style of the samples. Then, students are required to finish a writing task within the framework of the samples. The total 64 students in these two classes have never experienced network-based English writing training. They have received English writing courses for two semesters. Each week they got two hours' writing course in the traditional mode in which they are trained by teacher to appreciate the basic rules for construction of sentence, paragraphs through samples; they finish their writing assignment in paper and hand their writing papers into teacher without any revision. Each semester includes 16 weeks. They will have one more semester for English writing course. According to the experiment, 32 students in class1 are defined as control group 
because their English course is arranged in the traditional classroom and is taught in the traditional mode. Other 32 students in class 2 are considered as experiment group because they are taught in the blended learning mode: online network-based English writing learning mode +face-to-face learning mode in a computer classroom.

Table 3

The Mean Score of English Writing in the Pretest

\begin{tabular}{l|c|c|c|c|c}
\hline Class & Number of students & $\begin{array}{c}\text { Average score } \\
\text { of writing }\end{array}$ & Standard Deviation & T-Value & P-Value \\
\hline Experiment & 32 & 69.54 & 8.935 & \multirow{2}{*}{-.259} & .778 \\
\hline Control & 32 & 68.58 & 8.827 & \\
\hline
\end{tabular}

Table 3 shows that the average score of experiment group and control group is quite close. T-value for experiment group and control group is -0.259 , which is smaller than 2.000; P-value for these two group is 0.778 , which is bigger than 0.05 . therefore, it indicates that there is no significant difference between experiment group and control group in English writing ability. Then our experiment can be started.

Research Methodology. Based on the writing evaluation criteria from TEM4, the author has designed a writing evaluation criterion to record the scores in the pre-test writing. The new revised criteria attach much importance to the content, logical organization, persuasive ability, critical thinking ability. The specific evaluation proportion are as follows: content (20\%), logical structure (20\%), content sufficiency (25\%), language expression (35\%). language expression will be detailed as vocabulary $(15 \%)$, grammar (10\%), sentence (10\%). In order to testify the effectiveness of blended learning mode on the writing ability of English major students, the author makes a pre-test and post-test to make a contrast for their writing scores. The pre-test aims to ensure that the students both in control group and experiment group have no significant difference in their writing ability. Then, experiment group will be trained in the blended learning mode: network-based writing platform learning and face-to-face learning in the following 16 weeks, while the control group will be taught in the traditional mode---teacher-centered classroom teaching. After 16 weeks' learning is ended, the author will make a post-test to check how much the blended learning mode affect the students' writing ability. The statistic software SPSS22.0 will be used to make a comparative analysis of the average writing score in pre-test and posttest. Furthermore, P-Value will be calculated to testify whether there is a significant difference between the writing score in each evaluation aspect: content, logical structure, language expression. To ensure the reliability of scoring students' drafts, three college English writing teachers have worked together to grade each student's draft. The final score for each student's draft will be recorded as the average of three teachers' scoring.

Teaching Model of College English Writing within Blended Learning mode. The blended learning mode in this experiment will be designed according to Connectivism and Writing Process Approach. Connectivism pays attention to all levels of interaction within the network-based learning environment in which students have been trained to search and process the necessary information. Writing Process Approach focuses on the prewriting direction, draft revision instead of the final writing product. Therefore, online course platform learning mode plus face-to-face learning mode can offer a good combination mode to stimulate the interaction between students and social media, between students and teacher, between students themselves during the writing process. Based on the Writing Process Approach, writing is a recursive process in which one writing task can be revised many times. In this way, learners can reflect their draft, monitor their language expression, 
modify organization of their idea. As a result, their logical thinking and cognitive ability can be practiced and strengthened. Online course platform can provide students a channel to appreciate varieties of writing resources and make a large number of prewriting tasks. The online course platform can record every detail about the students' participation in the writing materials and prewriting activities, including their name, the time to log in, the content of their participation. According to students' participation in the activities of online course platform, teacher will design face-to-face activities to check how much students have finished and understood those online tasks. Based on the difficulties the students have shown, teacher makes more specific classroom teaching activities to help students to well-prepare for the first draft. The following figure will show the specific blended learning mode in our research.

Table 4

Blended Learning Mode in our Research

\begin{tabular}{lll}
\hline Online course platform learning & Writing process & \multicolumn{1}{c}{ Face-to-face learning } \\
\hline $\begin{array}{l}\text { Brainstrming; samples; } \\
\begin{array}{l}\text { Directions for writing strategy } \\
\text { Summaries for difficulties; }\end{array}\end{array}$ & prewriting & Task-checking \\
$\begin{array}{l}\text { More related samples } \\
\text { Training rules on the criteria to score; Incentive }\end{array}$ & First draft & $\begin{array}{l}\text { Group discussion; } \\
\text { Teacher's feedback }\end{array}$ \\
mechanism & correction; & Analysis of Students' writing \\
Good samples from students posted & Second draft & Teacher's feedback \\
\hline
\end{tabular}

It can be seen from table 4 that the blended learning mode is focusing on the writing process in which online course platform learning is combined with face-to-face learning. During each step of writing process, both online course platform learning mode and face-to-face learning mode have intervened in to ensure that students have fully participated in the designed activities. The combination of these two learning modes tries every means to train students' ability in analyzing samples, making enough preparation for writing. What's more, students have to learn by themselves in the online course platform and be checked in the face-to-face classroom teaching. They are trained to evaluate their peer's writing draft and make interaction with their peers, teachers, which can cultivate their cognitive ability to appreciate the logical structure, the development of idea in writing samples and students' samples. At the same time, diction of words and sentence have also been trained. Revision is an important part to develop students' writing ability. Therefore, in our blended learning mode, each student draft has to be revised twice with the help of peer's correction and teacher's feedback. To encourage the peer's correction, incentive mechanism has been stated in the online course platform. According to their comment on peer's writing draft, points from 5 to 10 will be recorded in their daily performance. After the writing draft has been revised twice, good writing samples from students will be selected to be posted in the online course platform as writing resources.

Online course platform in our research is innovated by Tsinghua University. Each course can be designed in this platform. It has several main modules: notice module, resources module, discussion module, writing assignment module, post area module, online test database module, students' management module. The following figure will show part of the modules for our online course platform. 
》通知公告

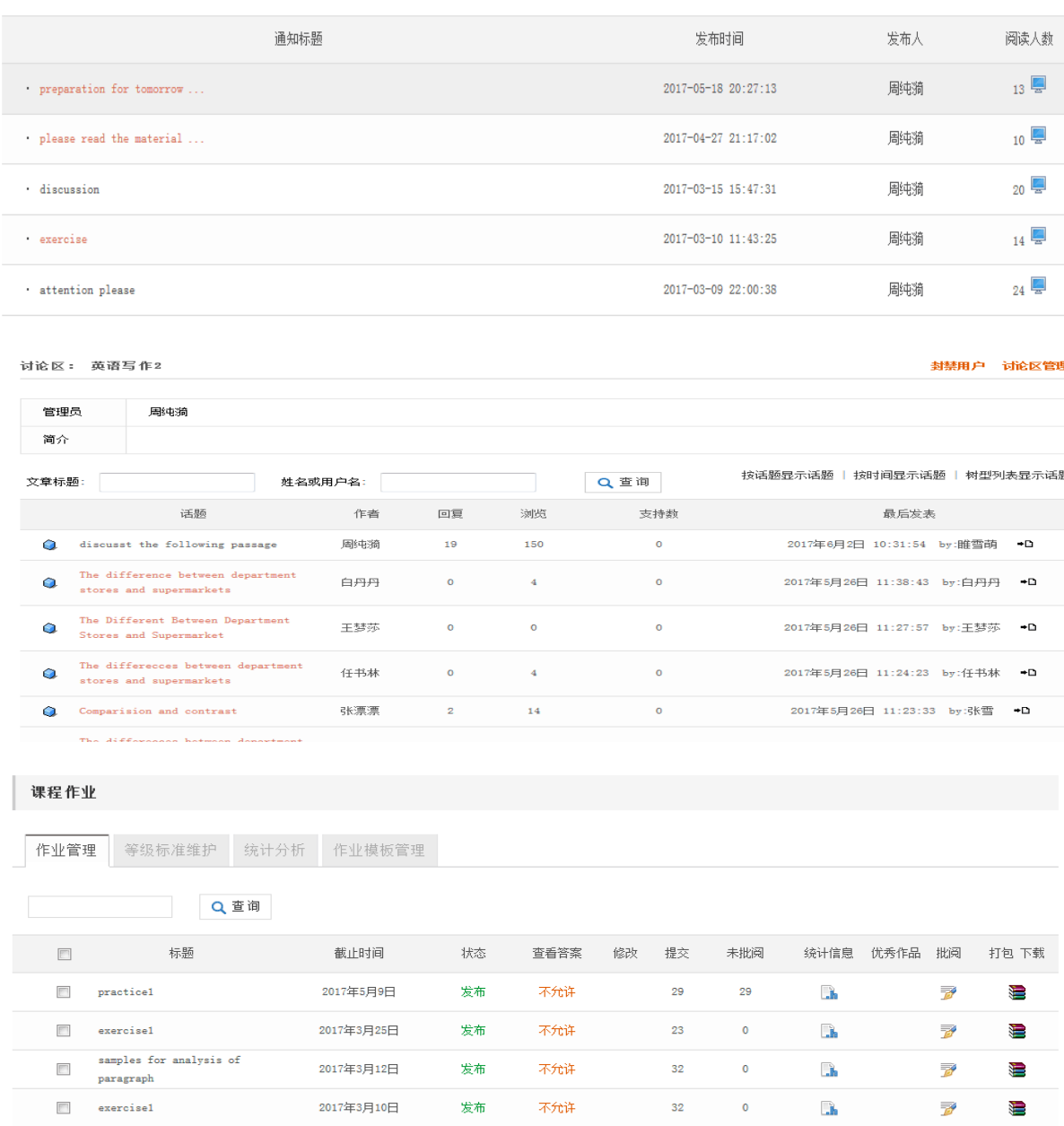

Figure 1. Notice module, discussion module and writing assignment module

The modules in the online course platform provide a detailed recording data for student's discussion frequency, their interaction frequency in the posted area, the time to read the notice module and to hand in their first draft, their revision participation in their peer's draft. At the beginning, students in the experiment group will be trained by teachers to know the location of each module in the online course platform. Furthermore, they have been taught to use main modules and know the function of each module. Therefore, the teaching model within the blended learning mode create a self-learning environment in which students are directed to participate in prewriting tasks and checked in the face-to-face classroom teaching activities. In the writing stage, online course platform provides students with a lot of writing samples and writing strategies as reference. Face-to face teaching will select some of students' first draft as sample to be discussed in the classroom and teacher give immediate feedback to their draft. In the revision stage, online course platform offers revision rules and 
incentive mechanism to students' self-learning. Face-to-face teaching will analyze some of student's revised draft to point out the problems they have made, which can give directions for their further revision of their peer's draft. In sum, it is quite clear that teaching model within blended learning mode can make a good combination of online learners' self-learning and face-to-face teacher's guidance.

\section{Research Procedure}

The research lasts for one semester, 16 weeks. The whole experiment will be designed in three stages: pretest, experiment, posttest. Pre-test aims to select the participants. During the experiment, the new teaching model combines the online course platform learning and face-to-face learning, which will be practiced in the experiment group for 16 weeks. The students in experiment group are trained to be familiar with the different modules in the online course platform, mainly including notice topic clarification module, discussion module, writing draft module. The traditional teacher-centered classroom teaching will be used in the control group for 16 weeks. In the new teaching model there are three main steps: prewriting step, drafting step, draft revision step. For each step, online learning activities is combined with teacher-guided classroom activities in English writing course. Revision is an indispensable part to develop students' logical critical thinking ability in English writing. Therefore, revision has been done according to the online strategies and classroom teacher's feedback. The final draft will be sent in the writing assignment module. But in the traditional class, students finish their writing tasks without their peer's revision and teacher's feedback, and immediately hand in their writing draft. After 16 weeks, students both in the experiment group and control group will attend the posttest. Pre-test and post-test are scored by average of three college English writing teachers. The comparative analysis of data in pre-test and post-test is calculated by software SPSS22.0.

\section{Results and Discussion}

\section{Results from Online Course Platform}

Students in experiment group have been guided to learn writing resources, prewriting activities and revision of peers' draft. The online course platform can automatically record the relevant information concerning the students' participation in the online learning activities. The following figure will show the interests for the students in experiment group to respond to the online learning activities. The result can indicate how much the students make interaction with the materials, with their peers and with their teacher.

The figure 2 mentioned above show that students made an active participation in the notice module, discussion module, peer's revision module. In the first day, 22 students of total 32 have finished reading the notices after the teacher writes down the announcement in the notice module. In the second day, 6 students do the job. In the rest three days, 4 students browse the notice. It means that majority of students can immediately respond to the activities in the prewriting stage and make a full preparation for the writing. In the peer's revision module, there are total 256 pieces of draft $(32 * 8)$ written down by students in which each student has finished one draft each week and they are suggested to have 8 weeks for writing assignment. Before the students log in 
to revise their peers' drafts, they have been arranged into 16 pairs in which 2 students work in a pair. Here are the total number of the peers' first draft revision. In the first day, 205 drafts of total 256 pieces have been revised. In the second day, 31 drafts have been checked. In the third day, 12 drafts have been examined. In the last two days, 8 drafts have been modified. It can be found that $80 \%$ of the students respond to the peers' revision in the first time, which indicates the students are eager to participate the revising activity. In the discussion module, there is a similar tendency. In each week the teacher will publish one discussion topic at least in the discussion module. The online platform records automatically the number of students' posting for the whole semester, showing a total 1085 pieces of students' posting. The figure 5 here suggests that in the first day, 636 posts have been published by students in which students interact with their peers and the teacher. In the second day, 205 posts have been submitted. In the third day, 98 posts have been handed in. In the last two days, 146 posts have been offered. In a sum, the results in figure 2 claim a general active tendency for students' participation in the online activities, including the prewriting stage and the revision stage.

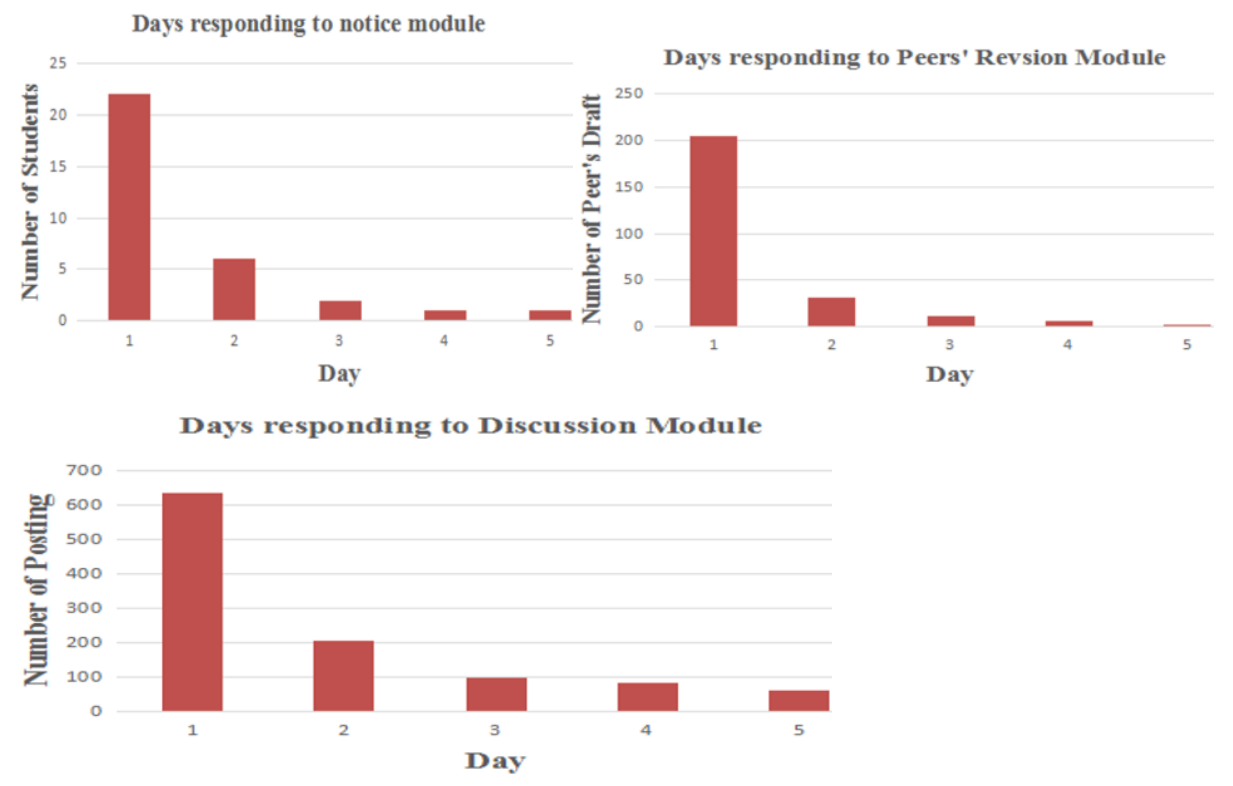

Figure 2. Days responding to different modules

Table 5

Online Course Platform Activities Participated by Students

\begin{tabular}{l|c|c}
\hline Prewriting activities & $\begin{array}{c}\text { Frequency to } \\
\text { log in }\end{array}$ & $\begin{array}{c}\text { Frequency of } \\
\text { posting }\end{array}$ \\
\hline Reading the samples & 829 & 102 \\
\hline Reading the directions for writing strategies & 905 & 212 \\
\hline 'Finishing the task & 780 & 245 \\
\hline Topic construction & 834 & 324 \\
\hline Techniques to develop passage in the 4 main style of writing & 928 & 305 \\
\hline Tough questions from peer's revision & 785 & 456 \\
\hline
\end{tabular}


The table 3 has shown that both control group and experiment group have no significant difference in the average score of pre-test writing. Therefore, the author put the blended learning mode into college English writing course for 16 weeks. The experiment group has accepted this new teaching model. After 16 week's training, the data concerning students' cognitive participation will be calculated in the following table.

The data in table 5 suggests that students in the experiment group actively participate the prewriting activities and discussion activities in the online course platform. In the terms of frequency to log in, students pay much attention to the techniques and strategies for English writing; students get a higher involvement in discussion activities and make more active interaction with the items concerning orgnizational skills or strategies. In the terms of frequency of posting, students show a less participation compared with their frequency of posting. It may result from the fact that posting need students to make more cognitive interaction with students, materials and teacher. But the difference in the frequency of posting shows an alternative tendency that students make more active participation in the discussion activities than it in the prewriting activities. It also indicates that students are eager to cultivate their ability in analyzing and commenting. Online learning platform creates opportunity for students to learn by themselves. Based on the problems they have met, they can post their questions and idea in the posting module. Their peers and teacher can make interaction with them. Therefore, the frequency of posting in the items related with questions and task are the highest.

\section{Results from Pre-test and Posttest}

Both pre-test and post-test are designed according to TEM4 because TEM4 aims to test students' ability in analyzing the social phenomenon and expressing their critical comment. In the 16 weeks, students from experiment group have been trained in the online course platform and face-to-face teaching to appreciate the classic samples and to revise their peers' drafts in terms of content, logical structure and language expression. Therefore, the post-test has focused on those three general aspects. Both control group and experiment group participate the posttest. The title of post-test is named as should cell phones be allowed in class? This test will be done in the classroom in one hour. The data from pre-test and post-test is displayed in the following tables.

The data from table 6 show the results of control group in the terms of content relevance, content sufficiency, organization structure and language expression, which are the four aspects to evaluate English major students' writing ability in our research. Content relevance is $20 \%$ in total $100 \%$ scoring, and content sufficiency is $20 \%$. Organization structure is $20 \%$. In addition, language expression are evaluated in the aspects of vocabulary (15\%), sentence (15\%), grammar (10\%). The paired sample T Test between pre-test and post-test in the control group suggests that the control group have no significant difference between pre-test and pre-test in the following four aspects: content relevance, content sufficiency, organization structure and language expression (vocabulary, sentence, grammar). In terms of content relevance, the mean value of pre-test is 14.837 and the mean value of post-test is 14.869 . The $\mathrm{p}$ value is $0.768>0.05$, which indicates there is no significant difference between pretest and post-test in terms of content relevance. In terms of content sufficiency, logical structure and language expression, it shows a similar tendency that there is no significant difference between pre-test and post-test 
Zhou / Empirical Study on the Effectiveness of Teaching Model of College English Writing within Blended Learning ...

$(\mathrm{P}=0.455>0.05, \mathrm{P}=0.563>0.05, \mathrm{P}=0.314>0.05)$. In a sum, the traditional teaching model (teacher-centered classroom teaching) cannot effectively improve the students' English writing ability. In the traditional classroom, teacher controls all the activities in which appreciation of classical samples are in the first place and the imitation of writing is followed. Students have no opportunities to develop their own topics and design their writing. What's more, they are not trained to revise their draft and their writing is done in one time. Although they finish their writing assignment, they do not monitor and reflect their idea in a constant and careful way. That is a natural result from writing theory: writing as a product, which pay attention to fixed structure and formal accuracy instead of writing content. But as writing as a process approach and technology move into English writing class, new teaching model has been coined. In the next part, the teaching model within the blended learning mode will be tested.

Table 6

Paired Sample T Tests from Control Group

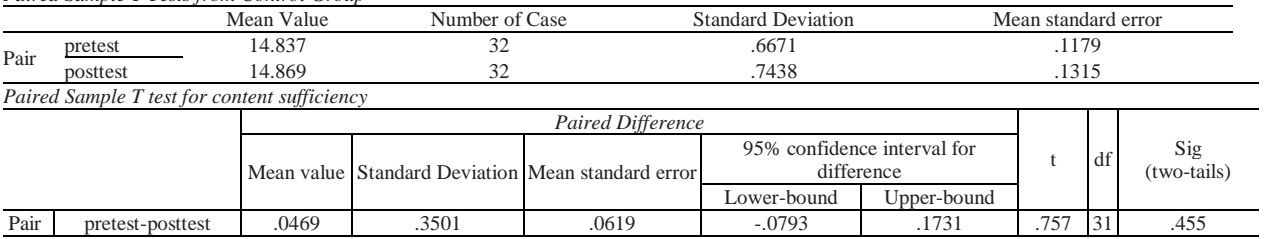

\begin{tabular}{|c|c|c|c|c|c|c|c|c|c|}
\hline & & \multicolumn{5}{|c|}{ Paired Difference } & \multirow{3}{*}{$\mathrm{t}$} & \multirow{3}{*}{ df } & \multirow{3}{*}{$\begin{array}{c}\text { sig } \\
\text { (two tails) }\end{array}$} \\
\hline & & \multirow[t]{2}{*}{ Mean Value } & \multirow[t]{2}{*}{ Standard Deviation } & \multirow[t]{2}{*}{ Mean Standard Error } & \multicolumn{2}{|c|}{$\begin{array}{l}\text { 95\% confidence interval for } \\
\text { difference }\end{array}$} & & & \\
\hline & & & & & Lower-bound & Upper-bound & & & \\
\hline Pair & pretest-posttest & -.0625 & .6047 & .1069 & -.2805 & .1555 & -.585 & 31 & .563 \\
\hline
\end{tabular}

\begin{tabular}{|c|c|c|c|c|c|c|c|c|c|}
\hline & & \multicolumn{5}{|c|}{ Paired Difference } & \multirow{3}{*}{$\mathrm{t}$} & \multirow{3}{*}{ df } & \multirow{3}{*}{$\begin{array}{c}\text { sig } \\
\text { (two tails) }\end{array}$} \\
\hline & & \multirow[t]{2}{*}{ Mean Value } & \multirow[t]{2}{*}{ Standard Deviation } & \multirow[t]{2}{*}{ Mean Standard Error } & \multicolumn{2}{|c|}{$\begin{array}{l}95 \% \text { confidence interval for } \\
\text { difference }\end{array}$} & & & \\
\hline & & & & & Lower-bound & Upper-bound & & & \\
\hline Pair & pretest-posttest & -.0625 & .3452 & .0610 & -.1870 & .0620 & -1.024 & 31 & .314 \\
\hline \multicolumn{10}{|c|}{ Paired Sample T Test for Content Relevance } \\
\hline & & \multicolumn{5}{|c|}{ Paired Difference } & \multirow{3}{*}{$\mathrm{t}$} & \multirow{3}{*}{ df } & \multirow{3}{*}{$\begin{array}{c}\text { Sig } \\
\text { (two-tails) }\end{array}$} \\
\hline & & \multirow[t]{2}{*}{ Mean value } & \multirow[t]{2}{*}{ Standard Deviation } & \multirow[t]{2}{*}{ Mean standard error } & \multicolumn{2}{|c|}{$\begin{array}{l}95 \% \text { confidence interval for } \\
\text { difference }\end{array}$} & & & \\
\hline & & & & & Lower-bound & Upper-bound & & & \\
\hline Pair & pretest-posttest & -.0312 & .5943 & .1051 & -.2455 & .1830 & -.297 & 31 & .768 \\
\hline
\end{tabular}

Paired sample $\mathrm{T}$ tests from table 7 suggests that students in experiment group have shown a significant difference between pre-test and post-test in terms of content relevance, content sufficiency, logical structure and language expression. In terms of content relevance, the mean value in pre-test is 14.838 and the mean value in post-test is 15.147 in the total 20 points. $P$ value is $0.003<0.05$, which indicates there is a significant difference between pre-test and post-test in terms of content relevance. In terms of content sufficiency, logical structure and language expression, it shows a high tendency that there is a significant difference between pre-test and post-test $(\mathrm{p}=0.000<0.05, \mathrm{p}=0.001<0.05, \mathrm{p}=0.000<0.05)$. The results from experiment group reveal that the teaching model within the blended learning mode have significantly improved English major students' writing ability. The new teaching model combines online course platform learning mode and face-to-face learning mode in which students are given opportunity to learn by themselves with the help of online course platform. This platform have several main modules, providing prewriting materials, tasks and writing strategies, interaction between students and teacher, revision peers' draft etc. Based on the online course platform, students can reduce 
their anxiety in writing and have more free time to finish the corresponding online tasks in which they can control their learning. The online course platform can automatically record each student's participation in the online-related activities, including time, frequency. Their participation will be graded in their daily performance, which can stimulate students to have a more active participation. In the discussion module, students are guided to discuss common mistakes shown from their peers' samples and do more strengthened tasks. During this process, they need to learn analysis and comment. In the peers' revision module, two students are in a pair and revise each other's draft in terms of content, structure, language. They are trained to make interaction with materials, their peers and teacher and reconstruct their knowledge network in which the critical thinking is cultivated. Thus, their ability to design content, structure is effectively improved.

Table 7

Paired Sample T Tests from Experiment Group

\begin{tabular}{|c|c|c|c|c|c|c|c|c|}
\hline 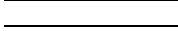 & \multicolumn{2}{|c|}{ Mean Value } & Number of Case & \multicolumn{2}{|c|}{ Standard Deviation } & \multicolumn{3}{|c|}{ Mean Standard Error } \\
\hline Pair pretest & \multicolumn{2}{|c|}{14.838} & 32 & \multicolumn{2}{|c|}{.6671} & \multicolumn{3}{|c|}{.1179} \\
\hline Pair $\frac{\text { posttest }}{2}$ & \multicolumn{2}{|c|}{15.147} & 32 & \multicolumn{2}{|c|}{.6653} & \multicolumn{3}{|c|}{.1176} \\
\hline \multicolumn{9}{|c|}{ Paired Sample T Test for Content Relevance } \\
\hline & \multicolumn{5}{|c|}{ Paired Difference } & \multirow{3}{*}{$\mathrm{t}$} & \multirow{3}{*}{ df } & \multirow[t]{3}{*}{$\begin{array}{c}\text { sig } \\
\text { (two tails) }\end{array}$} \\
\hline & \multirow{2}{*}{ Mean Value } & \multirow{2}{*}{ Standard Deviation } & \multirow{2}{*}{ Mean Standard Error } & \multicolumn{2}{|c|}{$95 \%$ confidence interval for difference } & & & \\
\hline & & & & Lower-bound & Upper-bound & & & \\
\hline \begin{tabular}{l|l} 
pair & pretest-posttest \\
\end{tabular} & -.3094 & .5450 & .0963 & -.5059 & -.1129 & -3.211 & 31 & .003 \\
\hline
\end{tabular}
Paired Sample T TEST for Organization Structure

\begin{tabular}{|c|c|c|c|c|c|c|c|c|}
\hline & \multicolumn{5}{|c|}{ Paired Difference } & \multirow[t]{3}{*}{$\mathrm{t}$} & \multirow[t]{3}{*}{ df } & \multirow{3}{*}{$\begin{array}{c}\text { sig } \\
\text { (two tails) }\end{array}$} \\
\hline & \multirow{2}{*}{ Mean Value } & \multirow{2}{*}{ Standard Deviation } & \multirow{2}{*}{ Mean Standard Error } & \multicolumn{2}{|c|}{$95 \%$ confidence interval for difference } & & & \\
\hline & & & & Lower-bound & Upper-bound & & & \\
\hline \begin{tabular}{l|l|} 
Pair & pretest-posttest \\
\end{tabular} & -.4687 & .7425 & .1312 & -.7364 & -.2011 & -3.571 & 131 & .001 \\
\hline
\end{tabular}

\begin{tabular}{|c|c|c|c|c|c|c|c|c|}
\hline \multicolumn{9}{|c|}{ Paired Sample T Test for Language Expression } \\
\hline & \multicolumn{5}{|c|}{ Paired Difference } & \multirow{3}{*}{$\mathrm{t}$} & \multirow{3}{*}{ df } & sig \\
\hline & \multirow{2}{*}{ Mean Value } & \multirow{2}{*}{ Standard Deviation } & \multirow{2}{*}{ Mean Standard Error } & \multicolumn{2}{|c|}{$95 \%$ confidence interval for difference } & & & \\
\hline & & & & Lower-bound & Upper-bound & & & \\
\hline \begin{tabular}{l|l|} 
Pair & pretest-posttest \\
\end{tabular} & -.2375 & .3180 & .0562 & -.3522 & -.1228 & -4.225 & 31 & .000 \\
\hline \multicolumn{9}{|c|}{ Paired Sample T Test for Content Sufficiency } \\
\hline & \multicolumn{5}{|c|}{ Paired Difference } & \multirow{3}{*}{$\mathrm{t}$} & \multirow{3}{*}{ df } & \multirow{3}{*}{$\begin{array}{c}\text { Sig } \\
\text { (two tails) }\end{array}$} \\
\hline & \multirow{2}{*}{ Mean Value } & \multirow{2}{*}{ Standard Deviation } & \multirow{2}{*}{ Mean Standard Error } & \multicolumn{2}{|c|}{$95 \%$ confidence interval for difference } & & & \\
\hline & & & & Lower-bound & Upper-bound & & & \\
\hline \begin{tabular}{l|l} 
Pair & pretest-posttest \\
\end{tabular} & -.1906 & .2704 & .0478 & -.2881 & -.0931 & -3.987 & 31 & .000 \\
\hline
\end{tabular}

\section{Discussion}

The results from online course platform above find that students in experiment group take an active participation in the activities of notice module, discussion module and peer's revision module in which $80 \%$ of the students respond to those prewriting tasks, revision tasks and discussion tasks in the first day. The difference in the frequency of posting claims a tendency that students make more active participation in the discussion activities than it in the prewriting activities. It also indicates that students are eager to train their ability in analyzing and commenting. Connectivism model in figure2 explains that with the support of social media the three interaction levels are closely associated with the cultivation of students' cognitive participation in learning activities. Social media produces a more complicated learning environment in which students develop their selflearning ability through interaction with online writing materials, peer's draft and teacher's feedback. The model also indicates that students are required to comprehend the information, analyze and comment mountains of online information in the wayfinding interaction and sensemaking interaction. Innovation is the most demanding 
interaction level in which students can generate the new basing on the level of analysis and comment. Knowledge growth is achieved when innovation is produced.

The teaching model within the blended learning mode provides students with a channel to make interaction with social media, prewriting materials, peers' draft and teacher's feedback. Online course platform creates a network learning environment and students are trained to finish online activities by themselves. But face-toface learning will check the problems from the online activities. Therefore, students have been guided to do self-learning. During different levels of interaction, students develop their critical thinking to analyze their peer's draft and comment their revision. Thus, their cognitive participation is highly involved. This can be explained from the result of pre-test and post-test in which students in experiment group show a significant improvement in their English writing ability. The new teaching model mainly focus on training students to appreciate their peers' drafts in terms of content, logical structure, language. Each draft needs to be revised twice on the peer's feedback and teacher's feedback. The constant revision is in line with the writing theory: writing as a Process approach. This approach proposes that writing is a recursive, nonlinear process. Taylor (1981) said that writing process is no longer a straightforward plan-outline-write process. In addition, Zamel (1983) put forward that writing is a nonlinear, exploratory, and generative process whereby writers discover and reformulate their ideas as they attempt to approximate meaning. Therefore, a typical teaching mode has four stages: prewriting, drafting, revising and editing. Blended learning mode creates a favorable learning environment in which students are encouraged to explore the writing by themselves, constructing an efficient composing process. They strengthen their awareness of commenting their peers' draft in the terms of meaning expression, structure and language use. Thus, it is natural that students in the experiment has gotten a significant improvement in their writing ability within the blended learning mode.

\section{Conclusion}

Connectivism is a learning theory generated in the digital learning environment. It proposes that learning not only reside in human being himself but also in nonhuman appliance. The connectivism model focuses on the four level of interaction: operation level, wayfinding level, sensemaking level and innovation level. Learners' cognitive participation are highly involved in these four levels of interaction. Online course platform functions as social media to build up the interaction between students and writing materials, between students and their peers, between students and teacher. The teaching model within blended learning mode attaches much importance to the writing process, which stems from the writing as a process approach. Zamel (1983) put forward that writing is a nonlinear, exploratory, and generative process whereby writers discover and reformulate their ideas as they attempt to approximate meaning. Writing as process approach pays attention to the recursive process in writing. There are generally four writing stages: prewriting stage, draft stage, revising stage and editing stage. Therefore, this paper has designed the writing process as prewriting, draft, twice revision. During this writing process, online course platform mode and face-to-face mode are working together to build 
up all four levels of interaction between students and writing materials, between students and their peers, or between students and their teacher. According to the connectivism model, students develop their cognitive ability to participate prewriting activities, drafting activities and revising activities in which they are required to make analysis of information and comment their peers' draft. The results from pre-test and post-test have revealed that the teaching model within the blended learning mode can significantly improve English writing ability for English major students. The effectiveness of this teaching model results from the guided self-learning environment in which the students train their ability to analyze, comment and innovate. Based on the constant interaction, their critical thinking has been strengthened. They have cultivated a strong awareness in commenting their peers' draft and tend to monitor their own writing process in terms of content, logical structure and language expression. They have found their own voice in designing writing topic, structure and content. Once again, the experiment results support the points of connectivism and writing as process approach.

\section{References}

Anderson, L. W., Krathwohl, D. R., Airasian, P. W., Cruikshank, K. A., Mayer, R. E., Pintrich, P. R., Raths, J., \& Wittrock, M. C. (2000). A taxonomy for learning, teaching, and assessing: A revision of Bloom's taxonomy of educational objectives, abridged edition. White Plains, NY: Longman.

Han, S. \& Hu, T.S. (2011). Study on English Writing Centre's Teaching mode Based on the Network Platform. Heilongjiang Researches on Higher Education, 9, 172-175. http://dx.doi.org/10.3969/j.issn.10032614.2011.09.054

Liu, B., Ge, L.L. \& Li, G.W. (2012). An Empirical Study on the Corpus-Based Teaching Model of College English Writing. Foreign Language and Literature, 28(4), 131-135. http://dx.doi.org/10.3969/j.issn.16746414.2012.04.027

Li, H. \& Liu, R.D. (2011). The Effectiveness of Collaborative Mode of College English Writing in the Network Platform. E-education Research, 219(7), 67-72.

Li, Z.X. \& Li, S.S. (2003). Reflection on the Present Situation of English Writing in China. Foreign Language World, 6, 55-60.

George, S. (2008). Connectivism: A learning theory for the digital age. Http:// www.elearnspace.org/Articles/connectivism.htm, Accessed February 20, 2008.

Taylor, B.P. (1981). Content and written form: A two-way street. TESOL Quarterly, 15(1), 5-13. http://dx.doi.org/10.2307/3586368

George, S. (2011). Orientation: Sensemaking and wayfinding in complex distributed online information environments 2011. Aberdeen: University of Aberdeen Doctoral dissertation.

Wang, Z.J. \& Chen, L. (2014). The Learning theory of connectivism and its latest development. Open Education Research, 5, 11-28. http://dx.doi.org/10.3969/j.issn.1007-2179.2014.05.003

Wang, Z.J. \& Chen, L. (2015). Theory framework building of instructional interaction in connectivism learning context. Open Education Research, 5, 25-34. http://dx.doi.org/10.13966/j.cnki.kfjyyj.2015.05.003

Yang, X.Q. \& Dai, Y.C. (2015). An empirical study on college English autonomous writing teaching model based on www.pigai.org. Technology Enhanced Foreign Language Education, 2,17-23. 
Zhou / Empirical Study on the Effectiveness of Teaching Model of College English Writing within Blended Learning ...

http://dx.doi.org/10.3969/j.issn.1001-5795.2015.02.003

Zamel, V. (1983). The composing processes of advanced ESL students: Six case studies. TESOL Quarterly, 17, 165-187. http://dx.doi.org/10.2307/3586647

Zhang, Y.H. (2008). The study on the dynamic assessment mode of online college English writing teaching. Foreign Language World, 127(4), 73-81. 